\title{
UJI IN VITRO AKTIVITAS ANTIBAKTERI DARI DAUN SIRIH
}

\author{
Oksfriani J. Sumampouw
}

\author{
Bidang Minat Kesehatan Lingkungan \\ Fakultas Kesehatan Masyarakat Universitas Sam Ratulangi Manado \\ Email: oksfriani82@yahoo.com
}

\begin{abstract}
Diarrhea remains one of the global problems, especially in developing countries such as Indonesia. Due to drug resistant strains, new antibacterial drugs are needed to be developed. The leaf extract of piper betle from a common fruit tree in Indonesia, including Minahasa in North Sulawesi Province, is used by the Minahasans for treating diarrhea. This leaf extract has inhibitive effects on populations of bacteria and parasites. The aim of this research was to prove the antibacterial effect of piper betle leaves on Escherichia coli. This research was conducted from December 2007 to June 2008 at the Fish Product Microbiology Laboratory of the Fisheries and Marine Science Faculty of Sam Ratulangi University, the Advanced Science Laboratory of Sam Ratulangi University, and the Chemical Laboratory of Mathematics and Natural Sciences Faculty of Sam Ratulangi University. This was an in vitro experimental research. The statistical test used to verify the effectiveness of piper betle extract as an antibacterial to E. coli was the Analysis of Variance (ANOVA), followed by the Least Significant Difference test (LSD). The conclusion of this research was that the extract of piper betle leaves had antibacterial activity on E.coli.
\end{abstract}

Keywords: piper betle leaf, antibacterial

\begin{abstract}
Abstrak: Diare masih menjadi sebuah masalah global, terutama pada negara negara berkembang, termasuk Indonesia, dan khususnya Minahasa. Hal ini disebabkan beberapa strain tertentu penyebab diare seperti Escherchia coli telah resisten terhadap obat-obatan. Oleh karena itu merupakan keniscayaan ditemukan senyawa baru sebagai antibakteri untuk mengobati diare. Ekstrak daun sirih yang umumnya ada di Indonesia, juga di Minahasa, telah sering digunakan sebagai obat anti diare. Ekstrak daun ini telah ditemukan dapat menghambat populasi bakteri dan parasit. Penelitian ini bertujuan untuk melihat aktivitas antibakteri ekstrak daun sirih terhadap E. coli. Penelitian ini dilaksanakan di Laboratorium Mikrobiologi Hasil Perikanan Fakultas Perikanan dan Ilmu Kelautan Universitas Sam Ratulangi Manado, Laboratorium Advanced Science Universitas Sam Ratulangi Manado dan Laboratorium Kimia Fakultas Matematika dan Ilmu Pengetahuan Alam Universitas Sam Ratulangi Manado pada bulan Desember 2007 sampai Juni 2008. Penelitian ini merupakan penelitian eksperimental secara in vitro. Uji statistika efektifitas antibakteri dari ekstrak daun sirih terhadap E. coli menggunakan Analysis of Variance (ANOVA), dan dilanjutkan dengan uji Least Significant Difference $(L S D)$. Hasil penelitian ini memperlihatkan bahwa ekstrak daun P. betle mengandung senyawa yang potensial untuk menghambat pertumbuhan $E$. coli
\end{abstract}

Kata kunci: daun sirih, anti bakteri

Dewasa ini obat tradisional masih tetap digunakan masyarakat dan mulai lebih nyata perannya. Hal ini disebabkan antara lain ketersediaannya (untuk keanekaragaman hayati Indonesia urutan kedua setelah Brazil), bernilai ekonomis dan merupakan pilihan alternatif. Berbagai cara pengobatan tradisional, yang merupakan warisan budaya kita, seperti penggunaan buah sirih (piper betle), daun mayana, madu, kuning telur 
dan "cap tikus" (minuman berkadar alkohol tinggi), acap digunakan masyarakat kita, terutama di daerah terpencil.

Menurut Hartini et al, masyarakat Indonesia telah melakukan pengobatan secara tradisional sejak dulu hingga saat ini. Berbagai tanaman obat, baik tunggal maupun ramuan telah dimanfaatkan serta berbagai upaya pengembangan telah banyak dilakukan. Kegiatan ini dilaksanakan untuk memaksimalkan pemanfaatan tanaman obat yang ada di Indonesia dan mencari alternatif obat baru oleh karena mulai terjadinya resistensi beberapa agen penyebab penyakit terhadap obat yang telah ditemukan terlebih dahulu. $^{1,2}$

Prayogo dan Suwondo menyebutkan bahwa sirih mempunyai kandungan kimia arecoline pada seluruh bagian tanaman yang berkhasiat sebagai anti-bakteri dan meningkatkan imunitas. Menurut Darwis, tanaman ini tersebar luas di Jawa, Madura, Bali, Aceh, Sumatera, Timor, Sulawesi, Ternate, dan Lampung. Daun sirih telah diteliti berkhasiat sebagai antibakteri dan sebagai peluruh dahak penderita tuberkulosis, sedangkan campuran dengan madu diyakini dapat meningkatkan daya tahan tubuh serta sebagai antibakteri. ${ }^{3-6}$

Sirih merupakan salah satu tanaman asli di Indonesia, dan tersebar luas di daerah Minahasa. Dengan pemanfaatan sirih sebagai tanaman obat untuk mengatasi berbagai macam penyakit tentu saja akan sangat membantu masyarakat Minahasa, baik dalam bidang kesehatan maupun ekonomi, apabila dibudidayakan. Mengingat harga obat yang semakin tidak terjangkau dan terjadinya resistensi kuman terhadap berbagai obat antibakteri, maka sirih merupakan pilihan yang layak dipertimbangkan.

Berlatar belakang uraian tersebut di atas maka dilakukanlah penelitian tentang manfaat daun sirih sebagai anti-bakteri, dalam hal ini terhadap E. coli.

\section{HIPOTESIS}

Ekstrak daun sirih dapat menghambat pertumbuhan Escherichia coli

\section{TINJAUAN PUSTAKA}

Sirih mengandung minyak atsiri, hidrosikavicol, kavicol, kavibetol, alilprokatekol, karvacrol, eugenol, p-cymene, cineole, caryofelen, kadimen estragol, terpenena, fenil propada, tanin dan sebagainya. Minyak atsirinya sendiri mengandung minyak terbang (betle phenol), seskuiterpen, pati, diatase, gula, zat samak serta kavicol yang memiliki daya mematikan kuman, antioksida dan fungisida (anti jamur).,

Sirih berkhasiat menghilangkan bau badan yang disebabkan oleh bakteri dan jamur. Daun sirih juga bersifat menahan atau menghentikan perdarahan (efek hemostatik), menyembuhkan luka pada kulit dan gangguan saluran cerna. Selain itu juga bersifat mengerutkan, mengeluarkan dahak, dan meluruhkan ludah. Menurut Suriawiria (2006), sirih dapat digunakan sebagai obat pada berbagai penyakit seperti batuk, sariawan, bronkitis, jerawat, keputihan, sakit gigi karena berlubang (daunnya), demam berdarah, bau mulut, haid tidak teratur, asma, radang tenggorokan (daun dan minyaknya) dan gusi bengkak (getahnya). ${ }^{7,8}$

E. coli merupakan bakteri yang hidup dalam saluran cerna hewan berdarah panas, termasuk hewan menyusui dan burungburung. Pertama kali diisolasi pada tahun 1885 oleh Theodor Escherich dan dinamai sesuai dengan nama penemunya. Escherichia, sebagaimana halnya Shigella, Salmonella, Citro-bacter, Klebsiella, Enterobacter, Serratia dan Proteus diklasifikasikan dalam famili Enterobacteriaceae. Escherichia dibedakan dalam beberapa spesies seperti coli, adecarboxylata, hermanii dan vulneris. ${ }^{9,10}$

Kelompok E. coli patogen dapat dibedakan menurut penyakit dan gejala yang ditimbulkan yaitu Enterophatoge-nic E. coli (EPEC), Enteroinvasive E. coli (EIEC), Enterotoxigenic E. coli (ETEC), Enterohaemorrhagic E. coli (EHEC) dan EPEC lainnya. ${ }^{9}$ E. coli merupakan bakteri Gram negatif berbentuk batang. Sel $E$. coli memiliki ukuran panjang 2,6-6,0 $\mu$ dan diameter $1,1-1,5 \mu$, tunggal atau berpasangan dan bersifat non-motil atau motil dengan flagela 
peritrikus. $^{11}$

Antimikroba merupakan senyawa alami, semi sintetik atau sintetik yang menghalangi atau membunuh organisme bebas, komensal atau patogenik, dengan sedikit atau tidak ada kerugian pada inangnya. Pelzcar dan Chan menyatakan bahwa antibiotik adalah substansi yang diproduksi oleh mikroorganisme sebagai metabolit sekunder dan dalam konsentrasi rendah dapat menghambat pertumbuhan atau membunuh organisme lain. Jadi, antibiotik merupakan bahan antimikroba yang dihasilkan oleh organisme hidup. $^{12-14}$

\section{METODE PENELITIAN}

Penelitian ini dilaksanakan di Laboratorium Mikrobiologi Hasil Perikanan Fakultas Perikanan dan Ilmu Kelautan Universitas Sam Ratulangi Manado, Laboratorium Advanced Science Universitas Sam Ratulangi Manado dan Laboratorium Kimia Fakultas Matematika dan Ilmu Pengetahuan Alam Universitas Sam Ratulangi Manado pada bulan Desember 2007 sampai Juni 2008. Penelitian ini merupakan penelitian eksperimental secara in vitro.

Pengujian antibakteri dilakukan dengan memasukkan sebanyak $50 \mu \mathrm{l}$ ekstrak sirih (menggunakan mikropipet) pada setiap sumur yang telah dibuat pada media Nutrient Agar. Media yang digunakan yaitu Nutrient Broth (NB) dan Nutrient Agar (NA). Sebagai media peremajaan bakteri digunaan media NA miring dalam tabung reaksi. Biakan bakteri diinokulasikan secara aseptik dalam tabung reaksi yang berisi NA miring steril masing-masing berjumlah tiga biakan murni, diinkubasikan pada suhu kamar selama 24 jam, diinokulasikan lagi ke NB, dan selanjutnya diinkubasikan selama 24 jam.

Teknik pengujian dikembangkan dari metode Kirby-Bauer. Metode yang digunakan pada pengujian aktivitas ialah metode difusi agar dengan cara sumur. Prosedur pengujian sebagai berikut :

1. Disiapkan media yaitu NA solid dan semi solid, masing-masing sebanyak $200 \mathrm{ml}$.
2. NA dibuat dengan cara: ke dalam erlenmeyer yang berisi $200 \mathrm{~mL}$ akuades dimasukkan peptone $1.0 \mathrm{gr}$, yeast exctract 0.6 gr, $\mathrm{NaCl} 1.0$ gr dan agar 3.0 gr untuk NA solid, dan 1.5 gr untuk NA semi solid. Setelah itu direbus hingga berwarna kuning bening atau larutan telah homogen, disterilkan pada suhu $121^{\circ} \mathrm{C}$ dan tekanan $15 \mathrm{psi}$, dan selanjutnya didinginkan sampai suhu $\pm 40^{\circ}$ $50^{\circ} \mathrm{C}$.

3. Secara aseptik NA solid dituangkan sebanyak 15-20 mL ke dalam cawan petri lalu dibiarkan sampai mengeras. NA solid yang telah dituang pada cawan petri steril dijadikan lapisan bawah.

4. Setelah mengeras, secara aseptik dituangkan sebanyak $10 \mathrm{~mL}$ NA semi solid yang telah dicampurkan bakteri uji sebagai lapisan pembenihan. Secara hati-hati dibuat sumur agar media sebagai lapisan pembenihan tidak rusak.

5. Setelah terbentuk sumur, maka dimasukkan ekstrak kasar bahan uji sebanyak $50 \mu \mathrm{l}$. Konsentrasi ekstrak yang diujicobakan yaitu $0 \%, 25 \%, 50 \%, 75 \%$ dan $100 \%$. Selanjutnya diinkubasikan pada suhu $37^{\circ} \mathrm{C}$ selama 24 jam.

6. Setelah itu, diamati dan diukur diameter zona hambat yang terbentuk yaitu daerah jernih di sekeliling sumur. Diameter zona hambat dapat dilihat pada Gambar 1. Data yang diperoleh akan dibuat persamaan linear sederhana, sehingga diperoleh persamaan linear dari antibiotik untuk setiap jenis bakteri.

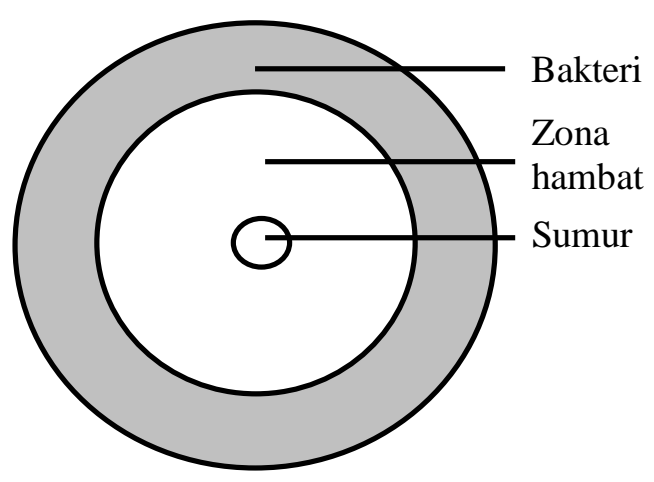

Gambar 1. Pengukuran aktivitas anti-mikroba berdasarkan pengamatan diameter zona hambat 
Aktivitas ekstrak sirih diukur dari luas zona bening yang terbentuk di sekitar sumur larutan uji dan dibandingkan dengan luas antibiotik pembanding. Pengujian ini dilakukan sebanyak tiga kali ulangan. Aktivitas antibakteri ekstrak uji dihitung berdasarkan persamaan yaitu:

$\mathrm{E}=\frac{\mathrm{N}}{\mathrm{Na}} \times 100 \%$

Keterangan :

$\mathrm{E}=$ Efektivitas antibakteri (\%)

$\mathrm{N}=$ Luas zona hambat antibiotik $(\mathrm{cm})$

$\mathrm{Na}=$ Luas zona hambat ekstrak uji $(\mathrm{cm})$

\section{HASIL PENELITIAN DAN UJI HIPOTESIS}

Penelitian aktivitas antibakteri yang dilakukan menggunakan metode sumur. Penelitian dilaksanakan dengan melihat daya hambat dari beberapa ekstrak uji yaitu ekstrak kasar daun sirih. Sebanyak $0.5 \mathrm{~g}$ ekstrak kasar ditambahkan ke dalam $1 \mathrm{ml}$ etanol 96\% kemudian ditambahkan $1 \mathrm{ml}$ air sedikit demi sedikit sambil divorteks. Larutan ini merupakan larutan dengan konsentrasi $100 \%$. Penambahan air dilakukan agar mengurangi efek membunuh bakteri dari etanol. Vorteks dilakukan dengan tujuan agar ekstrak uji bisa tercampur dengan baik. Ekstrak uji diencerkan sehingga menghasilkan konsentrasi $75 \%, 50 \%$, dan $25 \%$. Sebagai kontrol menggunakan larutan $0 \%$ yaitu aquades (Tabel 1).

Hasil penelitian aktivitas antibakteri dari ekstrak daun sirih terhadap E. coli pada cawan petri dapat di lihat pada Gambar 2.

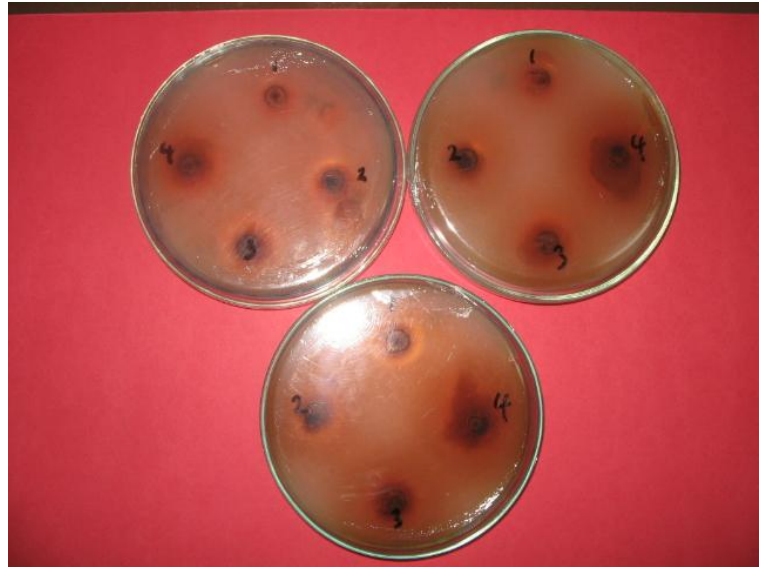

Gambar 2. Aktivitas antibakteri E.coli dari ekstrak daun sirih.

Hipotesis diuji dengan menggunakan uji sidik ragam (ANOVA) dan uji Least Significant Difference (LSD).

Hasil uji ANOVA dari diameter zona hambat E. coli menunjukkan nilai $\mathrm{F}$ (F hitung) yaitu 319,875 , lebih tinggi dari nilai $\mathrm{F}$ tabel pada tingkat kepercayaan 5\% $(\alpha=0,05)$ yaitu 3,48 . Hal ini berarti bahwa pengujian dari beberapa konsentrasi ekstrak daun sirih memiliki pengaruh yang bermakna pada zona hambat atau pertumbuhan dari E. coli.

Hasil uji LSD diameter zona hambat yang dihasilkan dari konsentrasi ekstrak 25\% (K1), $50 \%$ (K2), $75 \%$ (K3) dan $100 \%$ (K4) seluruhnya berbeda secara bermakna jika dibandingkan dengan diameter zona hambat dari konsentrasi 0\% (K0). Hasil ini menunjukkan bahwa konsentrasi ekstrak yang terbaik untuk menghambat pertumbuhan E.coli yaitu pada konsentrasi ekstrak $100 \%$ (K4). Hasil uji LSD dapat di lihat pada Tabel 2.

Tabel 1. Diameter (mm) zona hambat dari ekstrak daun sirih terhadap pertumbuhan E. coli

\begin{tabular}{cccccc}
\hline & $\begin{array}{c}\mathrm{K} 0 \\
(0 \%)\end{array}$ & $\mathrm{K} 1(25 \%)$ & $\mathrm{K} 2(50 \%)$ & $\mathrm{K} 3(75 \%)$ & $\mathrm{K} 4(100 \%)$ \\
\hline $\mathrm{n} 1$ & 0 & 28 & 35 & 50 & 50 \\
$\mathrm{n} 2$ & 0 & 25 & 30 & 48 & 55 \\
$\mathrm{n} 3$ & 0 & 22 & 38 & 47 & 50 \\
\hline Total & 0 & 75 & 103 & 145 & 155 \\
\hline Average & 0 & 25 & 34,33 & 48,33 & 51,67 \\
\hline Standard & 0 & \multirow{2}{*}{3,00} & 4,04 & 1,53 & 2,89 \\
Deviation & & & & & \\
\hline
\end{tabular}


Tabel 2. Hasil Uji LSD untuk melihat pengaruh konsentrasi ekstrak daun sirih pada diameter zona hambat terhadap E. coli

\begin{tabular}{ccc}
\hline Treatment & $\begin{array}{c}\text { Diameter rata- } \\
\text { rata zona } \\
\text { hambat }(\mathrm{mm})\end{array}$ & Notasi \\
\hline K4 $(100 \%)$ & $20,3 \pm 0,6$ & $\mathrm{~A}$ \\
K3 $(75 \%)$ & $15,3 \pm 1,1$ & $\mathrm{~B}$ \\
K2 $(50 \%)$ & $12,0 \pm 0,0$ & $\mathrm{C}$ \\
K1 $(25 \%)$ & $10,0 \pm 1,00$ & $\mathrm{D}$ \\
K0 (0\%) & 0 & $\mathrm{E}$ \\
\hline
\end{tabular}

Keterangan: Notasi yang berbeda menunjukkan adanya perbedaan

Hasil uji ANOVA dari efektivitas ekstrak daun sirih untuk menghambat pertumbuhan E. coli menunjukkan nilai $\mathrm{F}$ (F hitung) yaitu 319,875 , lebih tinggi dari nilai $\mathrm{F}$ tabel pada tingkat kepercayaan $5 \%$ yaitu 3,48 . Hal ini berarti bahwa pengujian dari beberapa konsentrasi ekstrak daun sirih memiliki pengaruh yang bermakna pada efektivitas menghambat pertumbuhan E. coli.

Hasil uji LSD efektivitas antibakteri $E$. coli yang dihasilkan dari konsentrasi ekstrak 25\% (K1), 50\% (K2), 75\% (K3) dan $100 \%$ (K4) seluruhnya berbeda secara bermakna jika dibandingkan dengan diameter zona hambat dari konsentrasi 0\% (K0). Hasil ini menunjukkan bahwa konsentrasi ekstrak yang terbaik untuk menghambat pertumbuhan $E$. coli yaitu pada konsentrasi ekstrak $100 \%$ (K4). Hasil uji LSD dapat di lihat pada Tabel 3.

Tabel 3. Hasil Uji LSD pada efektivitas antibakteri dari ekstrak daun sirih terhadap E. coli

\begin{tabular}{ccc}
\hline Perlakuan & $\begin{array}{r}\text { Efektivitas } \\
\text { antibakteri }\end{array}$ & Notasi \\
\hline K4 $(100 \%)$ & $50,8 \pm 1,4$ & A \\
K3 $(75 \%)$ & $38,3 \pm 2,9$ & B \\
K2 $(50 \%)$ & $30,0 \pm 0,0$ & C \\
K1 $(25 \%)$ & $25,0 \pm 2,5$ & D \\
\hline
\end{tabular}

Keterangan: Notasi yang berbeda menunjukkan adanya perbedaan

\section{BAHASAN}

Hasil pengujian aktivitas antibakteri dari ekstrak uji terhadap E.coli memperlihatkan bahwa daun sirih memiliki daya hambat. Hasil penelitian ini sejalan dengan penelitian yang dilakukan oleh Kurniawati ${ }^{15}$ bahwa sirih efektif untuk membunuh $E$. coli pada beberapa konsentrasi infus sirih. Hal yang sama juga dikemukakan oleh Nuringsih bahwa sirih memiliki minyak yang berfungsi sebagai antibakteri dan efektif untuk menghambat pertumbuhan dari E. Coli. ${ }^{15,16}$

Cowan menjelaskan bahwa sirih dapat digunakan sebagai sebagai antimikroba secara umum seperti bakteri, fungi dan protozoa. Aktivitas antibakteri dapat efektif pada bakteri Gram positif dan negatif. ${ }^{17}$

Dian $^{18}$ dalam penelitiannya tentang perbedaan khasiat antibakteri antara hidrogen peroksida 3\% dan daun sirih 20\% terhadap bakteri mix menemukan bahwa diameter zona hambat bakteri mix oleh daun sirih $20 \%$ lebih besar dari hidrogen peroksida $3 \%$. Arifin $^{19}$ yang melakukan penelitian untuk mengevaluasi aktivitas antibatuk ekstrak daun sirih menemukan bahwa ekstrak daun sirih memiliki efek antibakteri terhadap Haemophilus influenzas, Staphylococcus aureus dan Streptococcus haemoliticus.

Penelitian yang dilakukan oleh Rojas dkk. tentang aktivitas antimikroba dari 10 tanaman obat yang digunakan dalam pengobatan tradisional di Kolombia menunjukkan bahwa ekstrak sirih dan air memberikan respon aktivitas antimikroba terhadap Staphylococcus aureus, namun tidak efektif untuk Streptococcus $\beta$ hemolitic dan Pseudomonas aeruginosa. ${ }^{20}$

Guha $^{21}$ juga menjelaskan bahwa daun sirih dapat digunakan sebagai obat yang berfungsi sebagai antibakteri, antiprotozoa dan antifungi. Selain itu, dapat digunakan untuk menyembuhkan beberapa penyakit seperti abses, rematik, abrasi, histeria, mastoiditis dan sebagainya. Penelitian Guha menunjukkan bahwa aktivitas antibakteri ini terjadi karena daun sirih mengandung minyak atsiri yang di dalamnya terdapat senyawa fenol yang bersifat bakterisidal. Senyawa fenol apabila berinteraksi dengan dinding sel mikroorganisme akan menyebabkan terjadi denaturasi protein dan meningkatkan permeabilitas mikroorganisme. Interaksi antar mikroorganisme mengakibat- 
kan perubahan keseimbangan muatan dalam molekul protein dan menyebabkan terjadinya koagulasi. Protein yang mengalami denaturasi dan koagulasi akan kehilangan aktivitas fisologis sehingga tidak dapat berfungsi dengan baik. Perubahan struktur protein pada dinding sel bakteri akan meningkatkan permeabilitas sel sehingga pertumbuhan sel akan terhambat dan kemudian sel menjadi rusak. Selain itu, senyawa kavikol (memberikan bau yang khas pada daun sirih) memiliki daya bunuh bakteri lima kali lebih besar dari pada fenol. Senyawa kariofilen bersifat antiseptik dan anestetik lokal, sedangkan senyawa eugenol bersifat antiseptik dan analgesik topikal. ${ }^{21}$

\section{SIMPULAN DAN SARAN}

Setelah melaksanakan penelitian ini maka dapat ditarik simpulan bahwa ekstrak daun sirih (Piper betle) memiliki aktivitas antibakteri secara bermakna baik secara statistik maupun praktis, artinya hipotesis telah teruji kebenarannya.

Beberapa saran yang dapat diberikan yaitu :

1. Penggunaan ekstrak sirih dapat digunakan sebagai obat antibakteri, namun masih memerlukan penelitian lanjut secara in vivo.

2. Penelitian lanjut untuk melihat aktivitas antibakteri dari air rebusan bahan uji yang digunakan. Hal ini bertujuan memudahkan masyarakat dalam menggunakan tanaman uji sebagai obat antibakteri.

3. Berkaca dari beberapa kelemahan maupun kesulitan yang ditemui pada penelitian ini, maka untuk penelitian selanjutnya sebaiknya menggunakan pelarut yang bisa melarutkan ekstrak uji lebih sempurna.

\section{DAFTAR PUSTAKA}

1. Andries L. Efektifitas anti malaria dan toksisitas akut pada tikus serta aktifitas mikrosomal hati tikus (perfusi hati) dari ekstrak etanol buah sirih (Piper betle Linn). Laporan Penelitian DCRG/URGE.
Direktorat Jenderal Pendidikan Tinggi. Departemen Pendidikan Tinggi. Manado: Universitas Sam Ratulangi; 2000.

2. Hartini YS, Soegihardjo CJ, Putri AIC, Imaculata M. Daya antibakteri campuran ekstrak etanol buah adas (Foeniculum vulagare Mill) dan kulit batang pulasari (Alyxia reinwardtii BL). Laporan penelitian. Yogyakarta: Fakultas Farmasi UGM; 2007.

3. Prayogo B. Hendaknya pemanfaatan sirih untuk pelayanan kesehatan primer lebih ditingkatkan. Warta Tumbuhan Obat Indonesia 1992;1(1):1-3.

4. Suwondo S. Aktivitas antibakteri daun sirih (Piper betle L.) terhadap bakteri gingivitis dan bakteri pembentuk plak atau karies gigi (Streptococcus mutans). Warta Tumbuhan Obat Indonesia 1992;1(1):1-11.

5. Darwis SN. Potensi sirih (Piper betle L.) sebagai tanaman obat. Warta Tumbuhan Obat Indonesia 1992;1(1):9-11.

6. Januwati M, Rosita SM. Faktor-faktor ekologi yang mempengaruhi pertumbuhan tanaman sirih. Warta Tumbuhan Obat Indonesia 1992;1(1):1-9.

7. Suriawiria U. Daun sirih, obat serbaguna sepanjang masa. Surat Kabar Online Pikiran Rakyat. Edisi 26 Maret 2006 [cited 2008 Jan 10]. Available from: http://www.pikiranrakyat.co.id

8. Betel. [serial online]. 2007 [cited 2008 Jan 10]. Available from: http://www.wikipedia.com/betel.php

9. Escherichia coli. Wikipedia, The free encyclopedia. (serial online). 2007 [cited 2008 Jan 12]. Available from: http:// www.wikipedia.com/escherichia_coli

10. Brooks GF, Butel JS, Ornston LN, Jawetz E, Melnick JL, Adelberg EA. Jawetz, Melnick \& Aldeberg Mikrobiologi Kedokteran (Edisi 20). Jakarta: EGC, 1995.

11. Fardiaz S. Keamanan Pangan Jilid I. Jurusan Ilmu dan Teknologi Pertanian. Bogor: Intitut Pertanian Bogor, 1983.

12. Tkacz JS, Lange L. Antibiotika dan Infeksi. Jakarta: EGC, 1992.

13. Pelczar MJ, Chan ECS. Dasar-dasar Mikrobiologi. Jakarta: Penerbit Universitas Indonesia, 1988.

14. Nittcof R. Antibiotika dan Infeksi. Jakarta: EGC, 1986.

15. Kurniawati H. Membandingkan daya anti- 
bakteri infus sirih dengan minyak sirih secara invitro. Jurnal Penelitian Tanaman Obat di Beberapa Perguruan Tinggi di Indonesia. Jakarta: Pusat Penelitian dan Pengembangan Farmasi. Departemen Kesehatan Republik Indonesia; 1993.

16. Todar K. Antimicrobial agents used in treatment of infectious disease. University of Wisconsin-Madison Department of Bacteriology [online]. 2008 [cited 2008 March 13]. Available from: http://www.textbookofbacteriolgy.net/ant imicrobe

17. Cowan MM. Plant products as antimicrobial agents. Clinical Microbiology Reviews 1999;12(4):564-82. [cited 2008 March 13]. Available from: http://cmr. asm.org/cgi/content/full/12/4/564

18. Dian AW. Perbedaan khasiat antibakteri bahan irigrasi antara hidrogen peroksida $3 \%$ dan infusum daun sirih 20\% terhadap bakteri mix. Surabaya: Fakultas Kedok- teran Gigi Universitas Airlangga; 2007.

19. Arifin H. Evaluasi aktivitas antibatuk ekstrak air daun sirih. Jurnal Penelitian Tanaman Obat di Beberapa Perguruan Tinggi di Indonesia. Jakarta: Pusat Penelitian dan Pengembangan Farmasi. Departemen Kesehatan Republik Indonesia; 1993.

20. Rojas JJ, Ochoa VJ, Ocampo SA, Munoz JF. Screening for antimicrobial activity of ten medical plants used in Colombian folkloric medicine: A possible alternative in the treatment of non-nosocomial infections. Research Article. Biomedical Center Complementary and Alternative Medicine. 2006 [cited 2008 March 14]. Available from http://www.biomedcentral.com/1472-6882/6/2

21. Guha OD. Betel leaf: The neglected green gold of India. J Hum Ecol 2006;19 (2): 87-93. 